УДК 581.1

Журавльова I. M. http://orcid.org/0000-0002-3401-5476

\title{
ЗАСТОСУВАННЯМ ГІСТОХІМІЧНОГО МЕТОДУ ПРИ ВИВЧЕННЯ РОЗПОДІЛУ ВАЖКИХ МЕТАЛІВ В ПРОРОСТКАХ КУКУРУДЗИ
}

\author{
(C) Журавльова I. M. \\ Харківський національний педагогічний університет \\ імені Г.С. Сковороди, м. Харків \\ e-mail: i0660088587@gmail.com \\ https://doi.org/10.34142/ 2708-583X.2019.21.04
}

\begin{abstract}
В статті розглянуто вплив важких металів на ріст і розвиток проростків кукурудзи на ранніх етапах онтогенезу. Важкі метали надходять в рослину, головним чином, через кореневу систему. Тому в корені відбувається первинна реакиія рослини на їх вплив, яку можна чітко простежити за гальмуванням росту. В якості тест-культури використовували зерна кукурудзи. Насіння пророщували протягом трьох діб в темноті при $t=27^{\circ} \mathrm{C}$ на фільтрувальному папері, змоченому дистильованою водою. Триденні проростки пересаджували в чашки Петрі на фільтрувальний папір, змочений розчинами солей нітратів кадмію $\left(1 \times 10^{-4} \mathrm{ma} 5 \times 10^{-4} \mathrm{M}\right) \mathrm{ma}$ свинцю $\left(1 \times 10^{-3} \mathrm{ma} 1,5 \times 10^{-3} \mathrm{M}\right)$. Чашки Петрі витримували в термостаті при температурі $27^{\circ} \mathrm{C}$. Характер реакиї проростків кукурудзи на збільшення концентрації важких металів більш наочно виявився під дією іонів свинию і виражався у пригніченні ростових процесів.

Для виявлення місиь локалізації важких металів у тканинах рослин, запропоновано використання гістохімічного методу, який базується на утворенні забарвлених комплексів аналітичних реагентів 3 досліджуваними важкими металами. B якості такого реагенту використовувався дитизон, щцо характеризується високою чутливістю до кадмію та свинцюю. Після інкубації проростків з відповідними солями готували серію поперечних зрізів кореня, які помішували на предметне скло, наносили 3-4 краплі аналітичного реагенту, і через декілька хвилин розглядали під мікроскопом на різних збільшеннях. Локалізацію кадмію та свинцю визначали по червоному забарвленню тканин кореня. Було виявлено, щуо відкладення дитизонатів металів спостерігались в основному в тканинах ризодерми, екзодерми та мезодерми. В перициклі та иентральному ичиліндрі їх виявлено не було. Таким чином, досліди показали, щзо ендодерма грає бар'єрну роль у транспорті металів по кореню.
\end{abstract}

Ключові слова: важкі метали, забруднення, гістохімічний метод, дитизон, біоіндикатор

Швидкий розвиток промисловості в другій половині XX сторіччя спричинив відчутне забруднення навколишнього середовища і різке погіршення екологічної ситуації в різних регіонах планети. Серед численних забруднювачів найбільш ток-сичними, після пестицидів, вважаються важкі метали. Незважаючи на те, що багато важких металів не $\epsilon$ необхідними для життєдіяльності рослин, вони можуть активно ними поглинатися i проявляти тривалий негативний вплив та післядію на організм. Токсичні іони поглинаються рослинами і можуть потрапляти у інші живі організми. Це створює передумови до їх нагро-мадження в рослинній продукції, що, своєю чергою, призводить до інтоксикації тварин i людини. Саме тому дослідження багатьох вчених в останні десятиліття спрямовані на вивчення впливу важких металів на рослини [9-13]. Однією 3 найважливіших проблем екологічної фізіології рослин $є$ вивчення відповідної реакції рослин на іони важких металів, які при підвищених концентраціях надають токсичну дію на найрізноманітніші фізіологічні процеси. Ця проблема має не тільки очевидне практичне значення, яке 
визначається зростаючим забрудненням навколишнього середовища важкими металами, але також має i важливе фундаментальне значення, яке пов'язане 3 дослідженням механізмів адаптації та стійкості рослин до важких металів [1-2]. Останнім часом виникає інтерес щодо можливості використання рослин, як біоіндикаторів забрудненості навколишнього середовища важкими металами, що потребує знання закономірностей їх надходження в рослини та розподілу по органах та тканинах [3-8]. Для вирішення даних питань доцільно використовувати гістохімічні методи досліджень, які, нажаль, поки що недостатньо використовуються для вивчення локалізації важких металів в тканинах рослин [7].

Метою дослідження було визначити вплив важких металів на гістохімічні показники кукурудзи i проявлення токсичності важких металів до рослин.

\section{МАТЕРІАЛИ І МЕТОДИ}

Досліди проводили 3 проростками кукурудзи сорту «Харківська 325 МВ». Насіння пророщували протягом трьох діб в темноті при $\mathrm{t}=27^{\circ} \mathrm{C}$ на фільтрувальному папері, змоченому дистильованою водою. Триденні проростки пересаджували в чашки Петрі на фільтрувальний папір, змочений розчинами солей нітратів кадмію $\left(1 \cdot 10^{-4}\right.$ та $\left.5 \cdot 10^{-4} \mathrm{M}\right)$ та свинцю $\left(1 \cdot 10^{-3}\right.$ та $\left.1,5 \cdot 10^{-3} \mathrm{M}\right)$. Для контрольного варіанту використовували дистильовану воду. Проростки витримували в термостаті при температурі $27^{\circ} \mathrm{C}$. Під час ходу дослідження відбиралося по одному проростку для виготовлення гістологічного препарату.

Гістохімічний метод виявлення металів в тканинах рослин є якісним. За інтенсивністю фарбування можна судити про накопичення металу в клітинах і тканинах. В якості такого реагенту використовувався дитизон, що характеризується високою чутливістю до кадмію та свинцю. Для виявлення локалізації цих металів в рослинах після їх інкубації з нітратами кадмію та свинцю готували серію поперечних зрізів кореня, виконаних за допомогою леза (на різній відстані від апексу). Ці зрізи поміщували на предметне скло, на яке наносили 3-4 краплі дитизона, накривали покривним склом і через декілька хвилин розглядали під мікроскопом на різних збільшеннях. Локалізацію кадмію та свинцю визначали по червоному забарвленню тканин кореня [7].

\section{РЕЗУЛЬТАТИ}

В порівнянні 3 контрольним варіантом (рис.1) характер реакції проростків кукурудзи на збільшення концентрації важких металів більш наочно виявився під дією іонів свинцю і виражався у пригніченні ростових процесів (рис. 2).

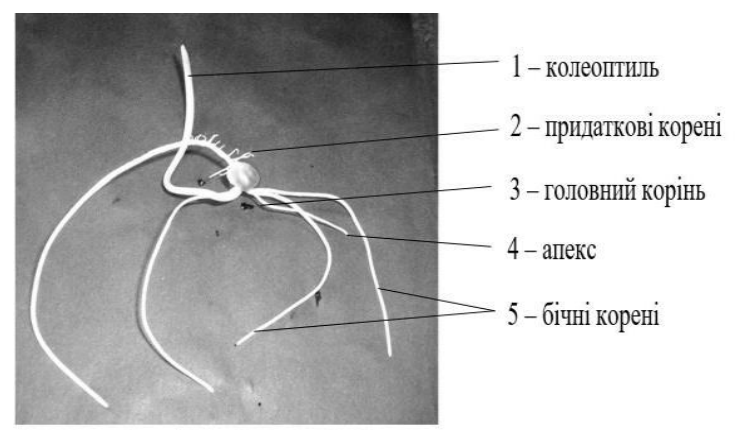

Puc. 1. Контрольний варіант (не забруднений важкими металами) 


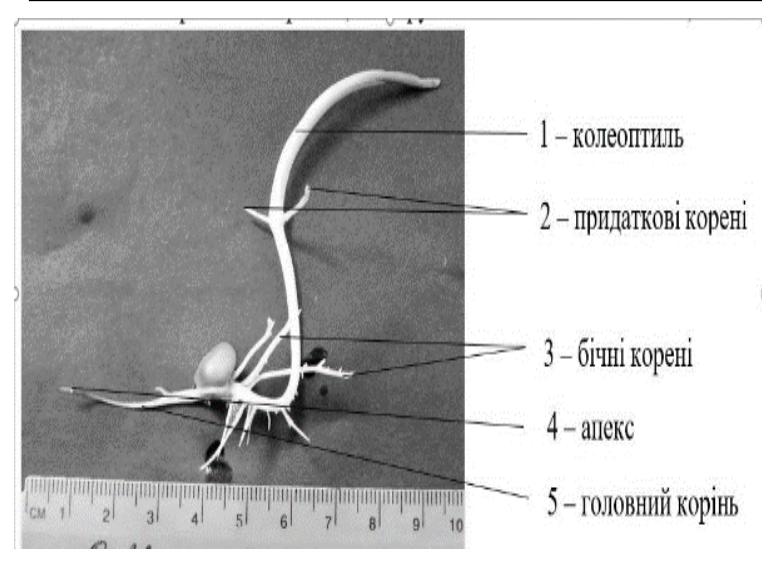

Puc. 2. Проросток кукурудзи, інкубований у розчині нітрату свинцю (конц. 1,5·10-3) протягом перших 24 год.

Для виявлення локалізації кадмію та свинцю в рослинах після їх інкубації 3 відповідними солями готували серію поперечних зрізів кореня на різній відстані від апексу.

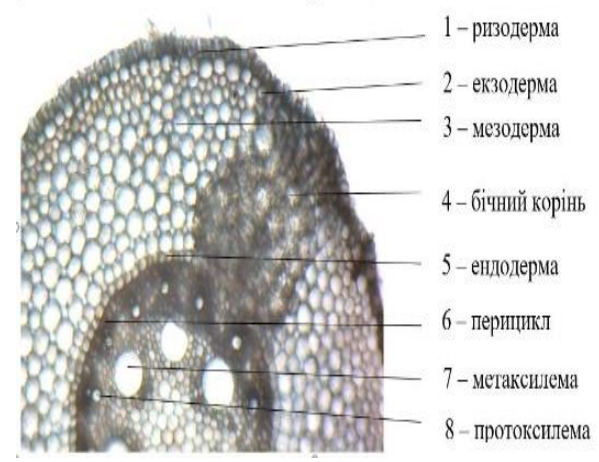

Рис. 3. Контроль. Зріз у зоні бічного кореня

В порівнянні 3 контролем (рис.3), на поперечних зрізах коренів, що розвивалися в розчинах 3 важкими металами, спостерігалось відкладання кадмію та свинцю у великих кількостях переважно в клітинах ризодерми та мезодерми кореня (рис.4, 5). В перициклі дитизонатів металів виявлено не було. Також солі важких металів не впливали на час розвитку бічних коренів, що узгоджується 3 результатами попередніх досліджень, які показали, що розгалуження коренів дуже стійке до дії різно-манітних токсикантів [5].

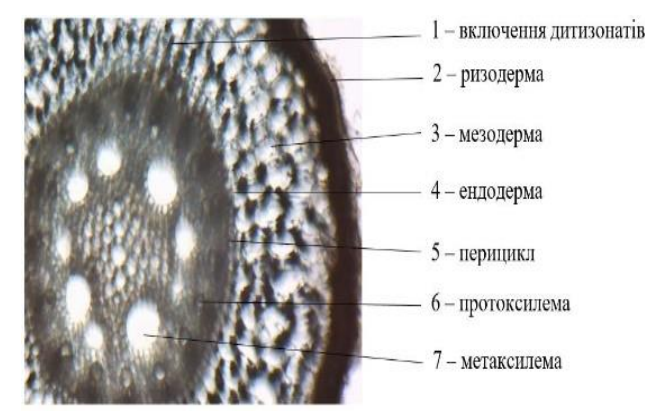

Puc. 4. Локалізація кадмію після його діï протягом 24 год. Зріз у зоні апексу:

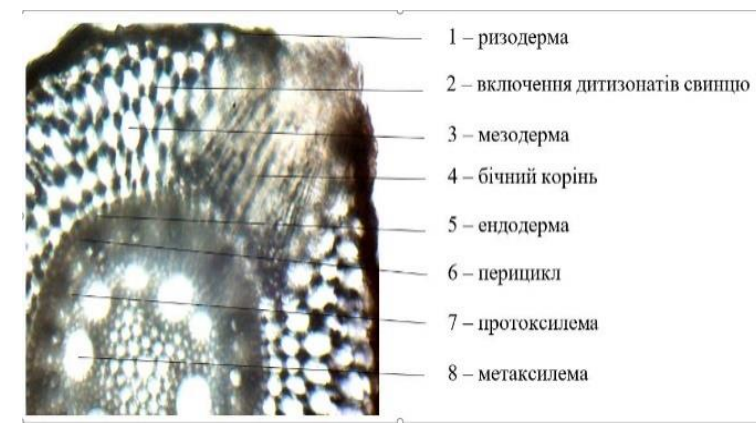

Puc. 5. Локалізація свинцю після його дії протягом 24 год. Зріз у зоні бічного кореня

\section{ОБГОВОРЕННЯ}

При інкубації рослин із використанням розчину нітрату свинцю при концентрації $1,5 \cdot 10^{-3} \mathrm{M}$ корені припиняли ріст протягом перших діб. Вони поступово темнішали від апексу до базальної частини. Кореневі волоски були практично непомітні. Хоча бічні корені 3'являлись в той же час, що і у контрольних коренів, в останньому випадку їх зачатки розподілялись достатньо рівномірно по довжині відповідної зони кореня, а в присутності кадмію і свинцю бічні корені частіше розташовувались групами. Також спостерігався розвиток розгалужених придаткових коренів (рис. 2), які зазвичай утво- 
рюються на більш пізніх етапах розвитку кореневої системи.

При гістохімічному дослідженні, починаючи з 24 год. інкубації, проявлялися помітні відмінності в розподілі свинцю i кадмію у рослинах, які вирощували при різних концентраціях металів. Характер розподілу металів по кореню був однаковий у всіх випадках. Проте за більшої концентрації забарвлення виявилось яскравіше, що свідчить про більш високе накопичення металів. При збільшенні часу інкубації проростків до 48 год. на розчинах 3 великою концентрацією важких металів, кадмій i свинець проявлялись у всіх тканинах кореня більш інтенсивно, ніж через 24 год. Також при цьому спостерігалось руйнування значної частини клітин первинної кори.

В коренях, які росли у розчинах 3 більшими концентраціями важких металів, кількість кадмію і свинцю помітно збільшувалась у тих самих місцях як і через 24 год. - кореневому чохлику, ризодермі та мезодермі. Через 120 год. проростки усихали i чорніли, а корені утрачали тургор i частіше забарвлювались у бурий колір.

\section{ПІДСУМОК}

Iз застосуванням гістохімічного методу встановлено закономірності бар'єрної функції кореневої системи по відношенню до кадмію і свинцю. Виявлено, що ці важкі метали затримуються клітинами мезодерми $\mathrm{i}$ ендодерми i тільки незначна їx кількість за великої концентрації проникає у провідні тканини кореня. Як ендодерма, так i клітини центрального циліндру, завдяки структурним особливостям їх клітинних стінок, запобігають проникненню цих важких металів в клітини перициклу, що обумовлює нормальне закладення бічних коренів.

\section{Список використаних джерел}

1. Huralchuk Zh.Z. Akumuliatsiia kadmiiu ta vmist elementiv mineralnoho zhyvlennia v roslynakh // Fiziolohiia roslyn v Ukraini na mezhi tysiacholit. K., 2001. - T. 1. - S. 183- 186. 17.

2. Huralchuk Zh.Z. Nadkhodzhennia ta detoksykatsiia vazhkykh metaliv u roslynakh // Zhyvlennia roslyn: teoriia i praktyka. - K.: Lohos, 2005. - S. 438-475.

3. Gural'chuk Zh.Z. Fi'totoksichni`st' vazhkikh metali`v ta sti jki`st roslin do yikh di yi. - K.: Logos, 2006. - 208 c.

4. Kaznyna N.M. Vlyianye svyntsa y kadmyia na rost, razvytye y nekotorye druhye fyzyolohycheskye protsessy odnoletnykh zlakov (rannye etapy ontoheneza): Avtoref. dys. kand. byol. nauk. Petrozavodsk, 2003. 23 s.

5. Serehyn Y.V., Shpyhun L.K., Yvanov V.B. Raspredelenye y toksycheskoe deistvye kadmyia y svyntsa na korny kukuruzy // Fyzyolohyia rastenyi. 2004. T. 51. S. 582-591.

6. Serehyn Y.V., Kozhevnykova A.D. Rol tkanei kornia y pobeha $\mathrm{v}$ transporte y nakoplenyy kadmyia, svyntsa, nykelia y strontsyia // Fyzyolohyia rastenyi. 2008. T. 55. S. 3-26.

7. Serehyn Y.V., Kozhevnykova A.D Hystokhymycheskye metody opredelenyia lokalyzatsyy tiazhelykh metallov y strontsyia y v tkaniakh vysshykh rastenyi // Fyzyolohyia rastenyi. 2011. T. 58, C. 617-623.

8. Terek O.I. Mekhanizmy adaptatsii ta stiikosti roslyn do nespryiatlyvykh faktoriv dovkillia // Zhurn. ahrobiol. ta ekolohii. - 2004. - T. 1, № 1-2. - S. 4156.

9. Das P., Samantaray S., Rout G.R. Studies on Cadmium Toxicity in Plants: a Review//Environmental Pollution, Vol. 98, No. 1, 1997. P. 29-36.

10. Kirkham M.B. Cadmium in plants on polluted soils: effects of soil factors, hyperaccumulation, and amendments // Geoderma. - 2006. - V. 137. - P. 1932.

11. Sanita di Toppi L., Gabbrielli R. Response to cadmium in higher plants //Environmental and Experimental Botany. 1999. Vol. 41. P. 105-130.

12. Stolt J.P., Sneller F.E.C., Bryngelsson T. [et al.]. Phytochelatin and cadmium accumulation in wheat // Env. Exp. Bot. - 2003. - V. 49. - P. 21-28

13. Wójcik M., Tukiendorf A. Cadmium uptake, localization and detoxification in Zea mays // Biol. Plant. - 2005. - N 2. - P. 237-245 
БІОЛОГІЯ ТА ВАЛЕОЛОГІЯ, вип. 21

\section{UDC 581.1}

\section{ANALYSIS OF THE DISTRIBUTION OF HEAVY METALS IN SEEDLINGS OF CORN BY MEANS OF THE HISTOCHEMICAL METHOD}

\section{Zhuravliova I.M.}

The article deals with the impact of heavy metals on the growth and development of corn seedlings on early stages of ontogenesis. Heavy metals enter the plant, mainly through the root system. Therefore, the primary reaction of the plant to their impact, which can be clearly traced through the inhibition of growth occurs in the root system. Corn was used as the test culture. The seeds were germinated for three days in the dark at $t=27^{\circ} \mathrm{C}$ on filter paper moistened with distilled water. Three-day seedlings were transplanted into Petri dishes on filter paper moistened with solutions of cadmium nitrate salts $(1 \times 10-4$ and $5 \times 0-4 \mathrm{M})$ and lead $(1 \times 10-3$ and $1.5 \times 10-3 \mathrm{M})$. The Petri dishes were kept in a thermostat at $27^{\circ} \mathrm{C}$. The nature of the reaction of corn seedlings to the increase of the concentration of heavy metals manifested more clearly under the action of lead ions and was expressed in the suppression of growth processes.

To detect the localization of heavy metals in the tissues of plants, we suggest the use of a histochemical method based on the formation of colored complexes of analytical reagents with the investigated heavy metals. Dithizone, characterized by high sensitivity to cadmium and lead, was used as such a reagent. After incubating the seedlings with the corresponding salts, a series of transverse sections of the root were prepared and placed on a glass slide. Then, 3-4 drops of the analytical reagent were applied, and after a few minutes the transverse sections were examined under a microscope at various magnifications. The localization of cadmium and lead was identified by the red staining of root tissues. It was found out that deposits of dithizonates of metals were observed mainly in the tissues of rhizoderm, exoderm and mesoderm. No metal dithizonates were detected in the pericycle and the central cylinder. Thus, the experiments have proved that the endoderm plays a barrier role in the transport of metals through the root.

Key words: heavy metals, contamination, histochemical method, dithizone, bioindicator

Стаття надійшла 24. 10. 2019 р. Рекомендована до друку на засіданні редакційної колегії після рецензуванн 